\title{
PARTISANSHIP, MEDIA AND THE OBJECTIVE ECONOMY: SOURCES OF INDIVIDUAL-LEVEL ECONOMIC ASSESSMENTS
}

Abstract: Economic voting studies have repeatedly shown that voter's assessment of incumbent economic performance is important for the vote decision. However, there is little work explaining how individuals form their economic assessments. Utilizing individual-level data from Turkey, we find that variation in retrospective assessments can actually be predicted by individual income growth rates over the previous year, and the association is stronger for pocketbook assessments. Nonetheless, partisanship and media are important sources of bias, especially for sociotropic assessments. Controlled for partisanship, viewers of pro-government media are more likely to think that the national economy has done better than their own household over the last year, and also more likely to believe that the economy would fare worse if the incumbent is replaced. The findings testify both to the capacity of the individuals to anchor their assessments to personal experience, and to the media's ability to weaken this anchor.

Keywords: economic voting, media, partisanship, public opinion, political economy, Turkey

Economic voting studies are based on the premise that individuals assess how the economy is doing while deciding on how to vote in the elections. What we do not know is where these subjective economic assessments come from. Recent scholarship highlights that the causal arrow between economic assessments and party choice points both ways; and partisans are likely to form evaluations of the state of the economy that are consistent with their previously held beliefs (Wlezien et al. 1997: Evans \& Anderson 2006). The literature also assumes that news media is a likely source of bias in the formation of economic assessments (Kayser \& Peres, 2012), but this has not been much studied at the individual level. This is an important gap in light of evidence indicating that partisan media can affect political behavior (DellaVigna \& Kaplan, 2007; Martin \& Yurukoglu, 2017) and incumbents may be influencing how the media frames economic news, especially in less-than-fullydemocratic settings (Levitsky \& Way, 2010; Rozenas \& Stukal, 2019). Lastly, voters' own experience with the economy should provide an objective basis of their assessments of the economy. Macro studies show that voter confidence in the economy is correlated with objective changes in aggregate indicators like GDP growth (Becher \& Donnelly, 2013; Brug 
et al. 2007; Nadeau et al. 2012), yet research on the objective sources of individual-level variation in subjective assessments about the economy has just begun (Healy et al. 2017).

In this article, we contribute to this research program by estimating individual economic assessments as a product of partisanship, pro-government media exposure, and income growth over the previous year. Our study relies on individual-level data collected in February 2018 with face-to-face interviews from a representative sample of the Turkish voting age population, and income growth simulated from a pseudo-panel surveyed monthly through the same sample selection and questionnaire methodology over the previous year. Our results both confirm basic assumptions about the economic voting mechanism and generate new evidence regarding how economic assessments are formed. We find that differences in individual retrospective assessments can actually be predicted by income growth rates, and the association is stronger for pocketbook assessments. However, partisanship and media are important sources of bias, especially for sociotropic assessments. We demonstrate that, controlled for partisanship, viewers of pro-government media are more likely to think that the national economy has done better than their own household over the last year, and also more likely to believe that the economy would fare worse if the incumbent is replaced.

Since our data are from the competitive authoritarian case of Turkey, there are limits to how one could generalize from these findings, however we believe that they are especially relevant to voter behavior in unconsolidated or backsliding democracies and hybrid regimes (Dominguez and McCann, 1995; Magaloni, 2006; Treisman, 2011). Our analysis suggests one explanation for why voters, without fooling themselves about their own economic situation, may keep supporting an incumbent who performs badly: When the economy is manifestly deteriorating, incumbents may try to use media influence to convince the electorate that the alternatives would be even worse. 


\section{The Formation of Economic Assessments: Theoretical Issues}

To provide tests of the idea of economic voting, the literature conventionally relies on surveys asking individual respondents about how they think the economy has performed over the past year (retrospective) and how they expect it to perform during the next year (prospective), from the vantage point of their own household (pocketbook) as well as the national economy in general (sociotropic). There are strong theoretical and empirical grounds to think that retrospective sociotropic evaluations, especially, are significant drivers of the vote choice (Lewis-Beck \& Stegmeier, 2000).

A revisionist line of thinking warns against putting too much faith in the traditional interpretations of existing findings because the association between economic assessments and political behavior is confounded by partisanship. Since people are inclined to minimize cognitive dissonance between various beliefs they hold, they will be likely to respond to survey questions about the economy in ways that confirm their wider beliefs about the incumbent party/leader, even if these beliefs were formed in little connection to actual economic changes (Anderson et al., 2004; Evans and Anderson, 2006). Developments in the field have confirmed that the positive effect of economic assessments on the vote survives various econometric controls for partisanship (Stevenson \& Duch, 2013 for a review). However, it is still not clear how economic assessments themselves are formed because individual-level studies have only recently begun to treat them as a dependent variable (Hansford \& Gomez, 2015; Healy et al. 2017). Macro studies point to a complex picture of mutual causation between "macro partisanship" i.e. aggregate levels of identification with rival parties, and subjective economic indicators such as consumer confidence (Erikson et al 2002). Since the mechanisms that generate these aggregations should spring from individual behaviour, more work is needed to understand how partisanship and the views on economic performance interact at the individual level. 
Two approaches to partisanship can be recognized in the literature on individual political behavior. The first, traced to Fiorina (1981), holds partisanship as instrumental and cognitively oriented. In this approach, voters keep a running tally of retrospective evaluations of party performances in their mind. Partisan identification is sensitive to short-term changes in recent government performance and issue stances; however, these effects will be tempered with already existing prior evaluations. An alternative perspective attributes greater durability and causal efficacy to the concept of partisanship, stressing that it is an expressive identity rooted in the need for group belonging (Campbell et al., 1960; Green et al., 2002). In this approach, partisanship is characterized by strong sentiments and unlikely to be influenced by short-term changes. Partisans frequently engage in motivated reasoning: information is selected and processed in a way to reinforce prior beliefs, instead of updating them. Recent research in this line stresses that partisanship is multidimensional; and negative partisanship — strong aversion towards a party—should be examined as distinct from positive partisan identification, since negative evaluations are not simply the bipolar opposite of positive ones. Abramowitz and Webster (2016), McGregor et al. (2015), Medeiros and Noel (2014) confirm that positive and negative partisanship both have significant consequences on political behavior and distinct covariates each. Positive partisans, negative partisans, and nonpartisans may be reacting differently to the news of a deteriorating economy then, and one of contributions is to distinguish between these groups' views.

Furthermore, voters do not always get the same news and this brings us to the second key concept of our study, media effects. Much of the voters' experience of the economy is mediated by news reports, therefore what kinds of news they are exposed to should affect their economic perceptions to a good extent (Mutz, 1992). Palmer and Duch (2001) and Alt et al. (2015) provide experimental evidence that manipulation of media cues changes economic assessment responses in surveys. The question of how viewership of real media outlets with 
different kinds of partisan slant are associated with economic assessments should follow. The importance of the media has been long recognized (Evans and Anderson, 2006; Fiorina 1981; Iyengar and Kinder 1987; Kayser and Peres, 2012; Wleizen et al., 1997) but more work needs to be done. As Goidel et al. (2010, p. 762) note, there is "a fairly consistent body of literature connecting content analysis of economic news coverage with aggregate economic expectations, but more limited analyses-both in number and scope-capturing the individual dynamics by which economic news coverage influences individual economic evaluations," and these analyses mostly ignore the variation between different media sources; perhaps because media polarization — especially on $\mathrm{TV}$ - has become a widely recognized fact of political competition in democracies only recently.

In the British context, for example, Sanders and Gavin (2004) examine whether the approval rating of the incumbent follows the aggregate monthly balance of news stories on BBC and ITV news programs. They are not interested in the variation between BBC and ITV because there is a high degree of correspondence between their coverage of economic views, and both apparently can be trusted to provide "a news service that, in the public interest, is free of party political bias" (p. 1251). Other studies in the British context similarly eschew studying variation between media sources with different partisan biases (Nadeau et al. 2000; Sanders et al. 1993). In their seminal work where they study the agenda-setting power of TV in the USA, Iyengar and Kinder examine material coming from a single media source-CBS Evening News; taking note of "American media's deep commitment to 'objectivity" (1987; p. 131). In a study that finds that media consumption negatively shape retrospective assessments, Hetherington (1996) does not examine the varying impact of different media sources, because apparently the entire US media had a negatively biased coverage of the economy under the incumbent president. Other individual-level studies similarly focus on the aggregate effects of different media sources, rather than their variation (Ansolabehere et al., 
2011; Duch et al., 2000; Gerber et al., 2009; Mutz, 1992; Weatherford, 1983) or analyse only variation between local and national news coming from the same news corporation (Goidel et al., 2010). Two important exceptions are DellaVigna and Kaplan (2007) and Martin and Yurukoglu (2017), who use variation in the availability of Fox News to measure this TV channel's effect on the Republican vote at the level of towns or individuals, but neither of these studies examine economic assessments.

A further issue that needs to be incorporated into the study of media effects is the incumbent abuse of state power to manipulate the availability of the good/bad economic news. The incumbent may do so by managing the public broadcasting agency or coaxing and coercing private media groups with carrots and sticks. This is particularly an issue in unconsolidated democracies and hybrid regimes, where electoral competition is serious but prerogatives of the public office are regularly exploited to advance partisan interests. Even in such a setting however, the incumbent's abuse of media is not guaranteed to be an effective persuasion tool: when pro-government propaganda seen on TV is too over-the-top, it may become a futile or even counter-productive method of affecting the audience's attitudes, as people learn to discount the slant of the news they encounter on partisan channels (Chiang and Knight 2011).

Partisanship and media are potentially important sources of bias for views on economic performance, but we contend that the objective economy should have some bearing on these views. So far this has not been studied much with individual-level data. Macroeconomic data on GDP growth and inflation rates provide explanans of changes in aggregate leader approval ratings and vote shares in time (Becher \& Donnelly, 2013; Brug et al. 2007; Nadeau et al. 2012), but they do not allow for individual-level variation. And it is obvious to most researchers that the economy does not affect all individuals at the same pace or direction (Stevenson \& Duch, 2013). For example, a policy decision to lay out government 
workers to reduce the deficit and service public debt would affect unemployed workers and holders of government debt quite differently, unless these are exactly the same people, which is unlikely. Kramer (1983) notes that partisan opponents who experience economic gains above the national average during the term of an incumbent will not necessarily change their vote behavior. This is true, but whether these individuals will be able to tell that they have been doing relatively well itself remains an open question, since their cognition may be conditioned by partisanship.

To answer this question individual economic circumstances should be traced and the literature has not developed a standard method to do this so far. Most individual-level research remains cross-sectional, and although panel data has become a more common feature in recent studies, none of these inquire about objective changes in individual economic circumstances that may be driving subjective economic perceptions (Evans \& Andersen, 2006; Fraile \& Lewis-Beck, 2014; Lewis-Beck et al., 2008; Lewis-Beck \& Costa Lobo, 2011; Tilley et al., 2018). One exception is provided by Hansford and Gomez's (2015) study of US data, who use county-level changes in local average income and unemployment as an instrument for the subjective assessments of respondents who are residents of these counties. Healy et al. (2017) go further by combining a representative election survey of Sweden with tax records providing data on survey respondents' personal income during the previous four years. They confirm - to our knowledge for the first time - that individual variation in subjective assessments of the economy, although biased by partisan identity, are meaningfully correlated with actual recent changes in income. In this article we take this research program further with data from Turkey.

\section{The Current Study: Context and Contributions}

We present a study of individual-level cross-sectional survey data. Our contribution lies in bringing together objective income growth, media exposure and negative as well as 
positive partisanship as sources of economic assessments; and utilizing limited but reasonable proxies for identification to address issues of endogeneity. To measure income growth it has not been possible to employ Healy et al.'s (2017) approach in Turkey, due to incompleteness of tax records and concerns about anonymity and security. Instead we tackle the same question with an alternative solution, which does not provide us with precise data on individual income changes but gives us a measure that is exogeneous to partisanship and economic views. What we do is generating predicted income changes for each individual by exploiting repeated cross-sectional surveys of Turkish voters surveyed monthly by the same research company (KONDA), based on the same sample selection and survey methodology over a period of two years (a database utilized in somewhat similar fashion by Marschall et al., 2016). Starting in February 2016, this survey series conclude with our February 2018 survey in which we record economic assessment responses. As will be detailed below, our strategy is first pooling reported monthly household income for the entire pseudo panel, adjusting them for monthly inflation, regressing income on certain demographic characteristics, thus arriving at predicted real income for 493 demographic groups, and secondly, generating predicted real income growth for these groups for a given period of interest. We will then see whether economic perceptions in February 2018 had a meaningful relationship with this proxy measure of real income growth over the previous period.

In the context of our case study the objective economy would face rivalry from media influence and partisan identities in shaping economic assessments. Partisanship is important in contemporary Turkey. There is rigorous scholarly debate over whether economic voting mechanisms work as the electorate becomes increasingly polarized between the religiously conservative supporters of incumbent Tayyip Erdogan's Justice and Development Party (AKP after its original initials), and the secular opponents (Başlevent and Kirmanoğlu, 2016; Kalaycioğlu, 2017). Moreover, with Erdogan adopting an increasingly autocratic governing 
style, contemporary Turkey has been considered as a competitive authoritarian regime (Esen and Gümüşçü, 2016). This kind of regimes are characterized by the presence of basic institutions of electoral democracy and a meaningful degree of competition for power, together with a highly uneven competition field favouring the incumbent party/leader due to the use of illiberal practices such as government harassment of media outlets (Levitsky and Way, 2010). In Turkey, such practices coexist with a vibrant electoral scene, which all parties take seriously. Over several elections, roughly half of the electorate has consistently voted against Erdogan and his party AKP, recently resulting in the incumbent loss of the mayoral race in Istanbul, for example. Thanks to the existence of competitive elections, media outlets that can be clearly identified as government-supported and having a pro-government bias in their news coverage, as well as media outlets who are allowed to articulate views associated with the opposition, this setting provides us with meaningful media variation.

At the time of our survey in February 2018, the country was experiencing early warnings of imminent economic hardship — debt-financed GDP growth accompanied by high inflation and deterioration in exchange rate, a situation that provided room for competing narratives offered by different media outlets. Utilizing simple content analysis of TV broadcasting in terms of how much time they devote to representatives of rival parties we are able to identify some TV channels as clearly pro-government media. Our data on media exposure is purely observational, relying on a survey question about which channel the respondent prefers for the news. Obviously, this raises the challenge of tackling endogeneity that may arise from reverse causation: TV choice may as well be an outcome of political opinion, in addition to causing it. We cannot completely solve this problem but we have three defence lines against it: First, we use strong controls for prior partisanship. Secondly, we present alterative models that utilize matching or instrumental variable approach (geographical location as an instrument for media exposure) to check for robustness. Thirdly, 
we put forward restrictive hypotheses that, if confirmed, will provide evidence that should be unlikely under a scenario of reverse causation. They rest on the idea that, while assessing the situation of the economy, as people have to judge questions that are farther away from personal experience, income growth should matter less and media should matter more and this should leave traces in the data. The next section develops these hypotheses.

\section{Hypotheses}

Simply put, voters should be checking the content of their pocketbook to judge the situation of the national economy, although their judgment will be biased by their already existing partisan orientations and the news they see on TV. The economic assessment measures we utilize include the two retrospective questions (pocketbook and sociotropic) conventionally used in the literature, referring to how the respondent's own and the nation's economic situation has changed over the last year respectively. We also include comparative prospective assessment: the respondent's view on whether the economy would improve, stay the same or affected badly if the incumbent was replaced by someone else. This is an assessment that brings together expectations about the future and a comparative judgment on the incumbent's competence; and has been shown to strongly predict voting behaviour in Mexico under PRI's competitive authoritarian regime (Dominguez and McCann 1995, Magaloni 2006). For all three measures, higher values indicate an assessment favourable to the incumbent.

H1: Individual income growth should positively influence retrospective assessments.

H2: Pro-government media should positively influence all economic assessments, controlling for partisanship.

H3: While positive partisanship towards the incumbent should bias economic assessments upwards, negative partisanship should introduce downward bias. 
H4: The influence of income growth should become smaller, and the influence of media should become larger as the dependent variable changes from pocketbook to sociotropic and to comparative prospective assessments.

H5: The associations between income growth and pocketbook assessments, between pocketbook and sociotropic assessments, and between sociotropic and comparative prospective assessments should be weaker among the viewers of pro-government media.

H4 and H5 refine intuitions that can be found in existing literature (Fiorina 1981; Funk and Garcia-Monet, 1997; Kayser and Peres, 2012; Kramer 1983; Magaloni, 2006). Consider a fully informed, perfectly rational voter whose pocketbook assessment adequately reflects her individual objective situation-defined in reference to the economic goals prescribed by her ideological orientation. So, if we denote pocketbook assessments as $P$, then:

$$
P=P(g, o), \quad P_{1},>0
$$

where $g$ is the individual's income growth rate over the past year, and $o$ is the set of demographic covariates including her political orientation.

The sociotropic assessment is about an object — the national economy - that is larger and more multi-dimensional than the individual's pocketbook. Therefore, in assessing this object, the voter has to rely to a greater extent on external sources of information because she has to ask herself not only "how have I done this year?" but also "how many people had an experience similar to mine?"- for which her own income growth cannot provide complete information. So, if we denote sociotropic assessments with $S$, then:

$$
S=S(P, u), \quad S_{1}>0
$$

where $u$ is the directional sum of the external information that the individual receives from her environment about everyone else's pocketbook. 
Comparative prospective assessments should include a further additional component that cannot be reliably known by any voter: how the economy would be managed by an opposition party/leader who perhaps has never even taken office before. So, if we denote comparative prospective assessments with $C$, then:

$$
C=C(S, r), \quad C_{1}>0
$$

where $r$ is a measure of how the economic is doing under a scenario where the incumbent is not in power. To arrive at a comparative prospective assessment, the voter has to compare this yet unrealized scenario with what she knows about the economy under the incumbent. If the $r$ is assessed to be less favourable than $S$, then $C$ would indicate an overall assessment favourable to the incumbent.

Observable implications of these equations follow: Since $S$ already includes additional variation not explained by $P$, and $C$ includes additional variation not explained by $S$, the association between income growth and assessments should grow weaker as the inquiry moves from pocketbook to sociotropic to comparative prospective assessments. What then should explain the portions unexplained by income growth $(o, u, r)$ ? The most viable candidate is the media. As Healy and Malhotra put it, "The pocketbook voter need only consult his bank account; the sociotropic voter can consult the news to assess the health of the economy" (2013: 286). This gives the H4. In addition, pro-government media outlets will tend to paint a positive picture of the incumbent economic performance regardless of the actual situation; therefore to the extent such media is influential the anchoring of assessments to real experience should be weaker among their audience. In other words, among the audience of pro-government media, the coefficient for $g$ should be smaller in an estimation of $P$, the coefficient for $P$ should be smaller in an estimation of $S$, and the coefficient for $S$ should be smaller in an estimation of $C$, compared to people outside the audience. This gives the H5. 


\section{Data and Measurement}

\section{Dependent Variables}

Our survey of economic assessments was conducted in February 2018 with face-toface interviews with 2687 respondents in a stratified selection of 154 neighborhoods and villages in 101 districts of 30 provinces in 12 socioeconomic regions of Turkey (Appendix A.2 for details). The economic assessment measures we utilize include the two retrospective questions (pocketbook and sociotropic) conventionally used in the literature, answered in a 5level Likert scale. We also include comparative prospective assessment: how the economy would perform if the incumbent was replaced. This measure could be preferred to have the same 5-level answer scale used for the conventional measures. However, after pretests of survey implementation we decided to simplify the answer scale for easier comprehension and so asked the respondents to choose from three responses, " $1=$ it would improve," " $2=$ it would remain the same," "3=it would deteriorate." Higher values favour the incumbent.

An additional economic assessment measure was used considering that the measures above connote to a valence judgment about national performance, raising the possibility that the respondents may tailor their answers on the basis of their wider view of the incumbent. An alternative strategy would be asking an open-ended question about the economy that includes no cues of government responsibility and no benchmark associated with a "desirable" answer. So we asked the respondents: "Say you were paying 100 kuruş for an item a year ago, how much in average are you paying for it now?" The answers give us the respondents' own perceptions about the price index. Since the responses are highly skewed, we use the natural logarithm in our analysis.

\section{Data on Income Growth}

To calculate the growth of incomes of people we surveyed in Feb 2018 we go back to data for people surveyed with the same methodology a year ago in 2017 (and as a robustness 
alternative, 2 years ago in 2016). After doing inflation adjustment, we estimate the observed income levels in 2018, 2017 and 2016 as a function of values on five demographic variables as observed at each time.

For this purpose, first, for the given time point $(t)$, we predict the logarithms of incomes $(\log (y))$ of each group $(i)$ by OLS regressions, which are equivalent to the following equation:

$$
\hat{y}_{i t}=e^{\beta_{0}+\beta_{1 r} \text { region }_{i t}+\beta_{2 e} e d u_{i t}+\beta_{3 d} \text { resid }_{i t}+\beta_{4 f} \text { female }_{i t}+\beta_{50} \text { occup }_{i t}}
$$

where region is the respondent's location in one of Turkey's seven geographical regions, edu is the level of education (primary school \& no degree, middle school, high school, university), resid is the type of residential area (rural, urban, metropolitan), and occup is occupation (capitalist/white collar, worker/artisan/farmer, retired, housewife, student, unemployed) and female denotes gender. Next, using the regression constant and the estimation coefficients for this estimation (see Table A.3.2 in Appendix), we impute income levels for each of the groups generated by combination of demographics, for each time point. For example, we predict the monthly income (in liras) of a high school graduate, worker/farmer/artisan woman who live in an urban area in Aegean region for January 2018February 2018 as:

$$
\hat{y}_{i t}=e^{6.025+0.582+0.259+0.212+0.052+0.236}=1581.3
$$

Based on the number of value categories on these 5 demographic variables, there could be a maximum of 1008 groups; however, incomes for only 493 groups can be predicted as the rest of the possible groups are empty (e.g. there aren't any observations for middle-school graduate retired women who live in rural Southeastern Turkey). The Pearson correlation coefficient between our predicted group incomes and household incomes observed in February 2018 is 0.447. 
Last, we calculate income growth for each group by simply taking the difference between imputed income levels for each period. For the 1-year period growth we use for the analyses reported in the article this is calculated as:

$$
g 1_{i}=\frac{\hat{y}_{i t}-\hat{y}_{i t-1}}{\hat{y}_{i t-1}}
$$

This, then, is the value for income growth $(g)$ for people surveyed in February 2018, who were asked the dependent variable questions and on whom we run our analyses. Depending on which group (defined by a combination of geography, settlement type, occupation, education and gender) they belonged to, they have a different predicted 1-year income growth rate, varying across 492 values.

\section{Data on Media}

We focus on TV channels as the media of interest because this is the only way most Turkish citizens access the news. ${ }^{1}$ Data on media consumption rely on the individual respondent's answer to the following question in our February 2018 survey: Which TV channel do you prefer most to view the news? Table 1 below lists the answers given by the respondents, together with their ratio in the sample expressed in Column I. Column II notes what percentage of viewers of each channel, according to our survey, report that they voted for the incumbents AKP in the previous election.

\footnotetext{
${ }^{1}$ A 2016 survey (KONDA, 2016) revealed that only 13.3 percent of Turkish households purchase newspapers and 39 percent state they read newspapers. Furthermore 72 percent state that they hear the news first from the TV and 15 percent use no other news sources (radio, print newspapers, websites or online applications) other than TV.
} 
Table 1 Audience composition and political affiliations for TV news in Turkey

\begin{tabular}{|c|c|c|c|c|}
\hline & \multicolumn{2}{|c|}{ Survey data } & \multicolumn{2}{|r|}{ Affiliation information } \\
\hline & $\begin{array}{l}\text { I) Ratio in } \\
\text { sample }(\%)\end{array}$ & $\begin{array}{c}\text { II) Viewers } \\
\text { who voted } \\
\text { AKP }(\%)\end{array}$ & $\begin{array}{c}\text { III) Time } \\
\text { devoted to } \\
\text { Erdogan or } \\
\text { AKP }(\%)\end{array}$ & IV) Ownership as of February 2018 \\
\hline Don't watch TV news & 15.7 & 20.6 & N/A & N/A \\
\hline A Haber* & 8 & 85.8 & 81.0 & Turkuvaz Medya (Zirve Holding) \\
\hline $\mathrm{ATV}^{*}$ & 14.7 & 77.7 & 81.8 & Turkuvaz Medya (Zirve Holding) \\
\hline CNN Türk & 2.5 & 25 & 61.1 & Doğan Yayın Holding \\
\hline Fox TV & 21.4 & 12.9 & 56.4 & Fox International Channels \\
\hline Haber Türk & 1.2 & 44.8 & 65.3 & Ciner Medya Grubu \\
\hline Halk TV & 1.7 & 2.4 & N/A & Estetik Yayın A.Ş \\
\hline Kanal 7* & 1.4 & 85.3 & 81.3 & Yeni Dünya Medya Grubu \\
\hline Kanal D & 7.4 & 36.3 & 61.7 & Doğan Yayın Holding \\
\hline NTV & 2.2 & 41.8 & 76.9 & Doğuş Holding \\
\hline Show TV & 4.1 & 52.6 & 67.2 & Ciner Medya Grubu \\
\hline Star TV & 3.7 & 38.8 & 66.9 & Doğuş Holding \\
\hline TRT and TRT Haber* & 11.1 & 72.6 & 91.2 & State agency \\
\hline Other channels & 4.9 & 51.4 & N/A & N/A \\
\hline Total & 100 & 44.3 & & \\
\hline
\end{tabular}

* Pro-government. Column III reports, based on official RTUK data, minutes devoted to AKP representatives in addition to President Erdoğan during the propaganda period before the 2017 referendum. See Appendix A.1 for details.

While every media outlet in Turkey has to do business with anticipated government reactions in mind, not all do this happily or to an equal extent. We identify four TV channels as pro-government media as of February 2018, based on existing literature and a simple content analysis. Among these four, TRT is Turkey's public broadcasting institution, and currently it has an unmistakable pro-AKP and pro-Erdogan accent. Secondly, ATV is Turkey's most viewed private TV channel, originally founded by secularly oriented businessmen. It was sold in 2007 to the pro-AKP business conglomerate Çalık, and then in 2014 to another one-Zirve Holding. Both of these acquisitions were visibly connected to Erdogan's increasing influence over the mainstream media: Çalık's CEO was Berat Albayrak, currently Erdogan's son-in-law and Turkey’s Minister of Finance and Treasury. Zirve Holding's media branch Turkuvaz is managed by Serhat Albayrak-Berat's brother; and the holding's flagship firm Kalyon has become one of the world's top ten infrastructure 
firms through government contracts under AKP governments. ${ }^{2}$ ATV still targets the higherincome, centrist segments of the viewership market with attractive gameshows and the like; however, its news coverage has become clearly pro-government especially in the highly polarized post-2014 period. The third channel we identify is A Haber, which is a news-only TV channel that is run under the same Zirve-Turkuvaz media group. The last channel is the moderately Islamist Kanal 7, which is best known for having Zahid Akman as its chief editor. Akman served as the head of the RTUK (the public institution for monitoring TV content for compliance with laws) under AKP until being involved in a major scandal involving alleged government corruption (for a premier to government-media relations in Turkey; see Freedom House, 2014).

While to close observers of Turkish politics the political affiliations of TV channels may be obvious, they should be best confirmed with systematic content analysis. We can do this thanks to an independent research conducted just before the last (prior to the survey date) major polarizing political event in the country, the referendum held in April 2017 on the transition from a semi-presidential to a fully presidential system. For the referendum, President Erdogan and his party AKP enthusiastically advocated an affirmative vote, while the other parties remained either ambivalent or opposed to the idea. Through content analysis, the research analysed time devoted in news stories to covering the representatives of each party in addition to the President Erdogan himself (or his presidential advisors) during a 20day period in March 2017. ${ }^{3}$ The Column III of Table 1 lists time devoted to AKP and President Erdogan as a share of total time for all parties in the parliament. The ratio surpasses 80 percent for all four TV channels we identify as "pro-government" and for no other

\footnotetext{
2 See "Top 10 sponsors by investment and region, 1990-2017" in World Bank's Private Participation in Infrastructure Database, https://ppi.worldbank.org/snapshots/rankings.

${ }^{3}$ The research was conducted by Ersin Öngel, a board member of RTUK, in cooperation with the NGO Demokrasi İçin Birlik, based on official RTUK data. Descriptive tables are available at https://bianet.org/english/society/184769-allocation-of-broadcast-time-on-tv-53h-for-erdogan-17h-for-chp-33min-for-hdp. See Appendix A.1 for details.
} 
channel. News coverage is not always in a positive light, so appearance in news may not mean endorsement. Alternative information may be gleaned from decisions about livebroadcasting a speech by a politician or hosting them in live debates. Live coverage data (see Appendix A.1) confirms the premise: The ratio of time devoted to AKP and President Erdogan is above 90 percent for the same four channels and for no other channel. In short, if voice allocation has a status conferral function (Çarkoglu et al., 2014; Ferree et al. 2002), there is reason to consider that TRT, ATV, A Haber and Kanal 7 as pro-government media. Viewers of these four TV channels are coded 1 for pro-government media and 0 for everyone else.

Unlike the USA, there are no exclusive and competitive cable networks in Turkey and all major channels are practically available to anyone with a TV. This bars us from using availability as an exogeneous instrument for media exposure like DellaVigna and Kaplan (2007) or Martin and Yurukoglu (2017) did. What we do instead is controlling — through both matching and regression-for an extensive list of demographic variables that could confound the relationship between media choice and political behavior, including partisanship. Fortunately, both supporters and detractors of the incumbents can be found among the audience of pro-government TV. This is because people tune into these channels for the entertainment value and get exposed to news reporting as a side product: On days when there is a highly popular TV series, the evening news section on the same channel also receives higher viewership ratings, despite the news is always presented by the same person. For the three-month (1 November 2017 to 31 January 2018) period preceding our final survey, the correlation for the viewership ratings of evening news and the follow-up entertainment program across 92 days was 0.42 for ATV and 0.41 for TRT, both significant at $1 \%$ level. ${ }^{4}$ In

\footnotetext{
${ }^{4}$ Data from http://www.ranini.tv/reyting/. Rating is the audience of a particular program at a specific period of time expressed as a percent of the audience population. For the less popular pro-government channels Kanal 7 and A Haber there is no comparable rating data. Among the top non-pro-government TV channels, there was 0.44 correlation $(\mathrm{p}<0.01)$ for Kanal D and no significant correlation for Fox TV. Details: Appendix A.1.
} 
other words, people with random partisan orientations may also watch pro-government news because they happen to like the entertainment content offered at the same channel.

\section{Data on Partisanship}

To operationalize partisanship as a running tally (Fiorina 1981), a simple solution is to focus on the last vote cast by the citizen, since this can be taken to imply where the tally stood during the last time period. Accordingly, we assume that simply having voted for the incumbents $\mathrm{AKP}$ in the last election (for which we rely on recalled vote reported in our survey $)^{5}$ should introduce an upwards bias to how individuals process and react to information about the government's performance, regardless of whether the information is generated through daily experience or coming from external sources like the news media. ${ }^{6}$

To capture the more durable, positive and negative partisanship identities, two questions in our survey gives relevant information: "Is there a party that you would always vote for, under any circumstance?" and "Is there a party that you would never vote for, under any circumstance? If the answer given to these questions is AKP, then we code 1 for positive and negative partisanship, respectively; and 0 otherwise. We use this information about positive and negative partisan identity towards the incumbents to construct a 4-fold partisanship status variable, crossing it with information about the individual's vote from the last election. Figure 1 illustrates how the groups are constructed and their sizes.

\footnotetext{
${ }^{5}$ Although Turkey has been in a period of transition to Presidential rule, as of February 2018 the last election that directly mattered for the composition of the current executive was the Parliamentary election of November 2015.

${ }^{6}$ We also replicated the analyses by inserting a dummy for recalled MHP vote, a right-wing party that forms electoral alliances with the incumbents AKP, Results remain substantially unchanged.
} 


\section{All respondents who were of voting age during last election}
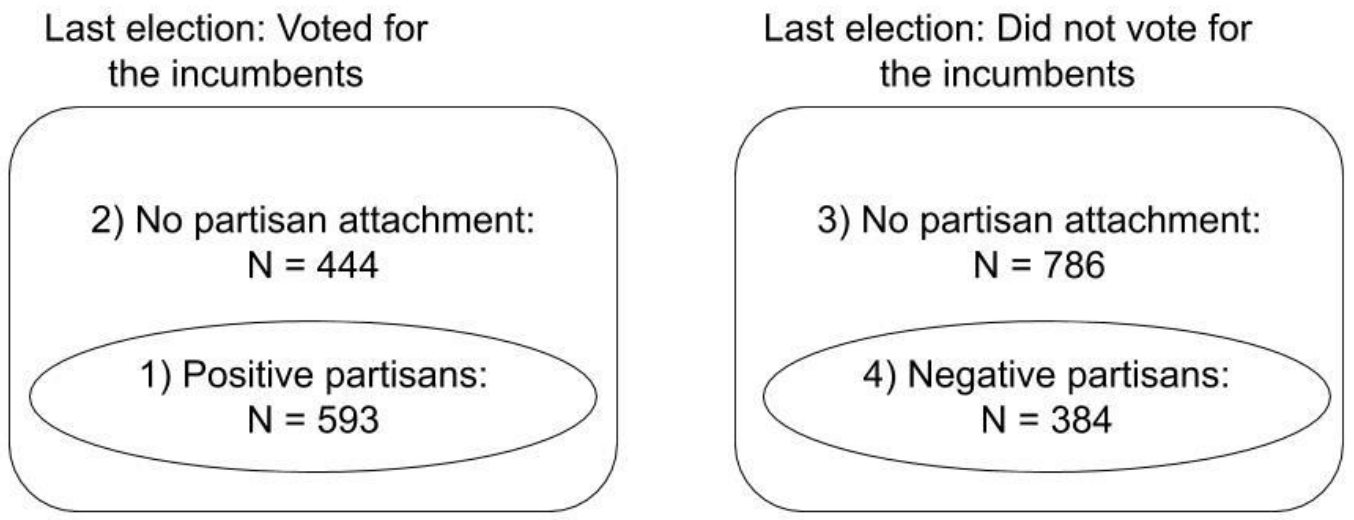

Dropped observations: Negative partisans who voted for the incumbents $(\mathrm{N}=8)$, positive partisans who did not $(\mathrm{N}=26)$, those reporting both positive and negative partisanship towards the incumbents $(\mathrm{N}=10)$

Figure 1: Construction of partisanship groups

The first group, whom we call as "partisan pro-incumbents", are those who already voted for the incumbents and who identify with them positively. The second group, whom we call as "swing pro-incumbents" are those who voted similarly but who do not express a strong partisan identity. The third group, "swing opponents" are those who did not vote for the incumbents but who may consider voting for them in the future since they too lack a partisan identity. The fourth and last group, "partisan opponents," are those who did not vote for the incumbents and have a negative partisan stance against them.

\section{Analysis}

We will regress economic assessments on the simulated 1-year income growth (in \% terms), partisanship status (in 4 categories), and government media viewership (binary). In addition, we first employ limited controls, including two variables that are the staple of economic voting studies: current monthly personal income level observed (in 1000 liras) to control for class, and left-to-right self-placement (1-10) to control for ideological preferences. Table 2 presents the results. Three findings stand out: First, partisanship is highly influential: Compared to the baseline group of partisan pro-incumbents, the other three groups have 
significantly lower economic assessments and a higher perception of the price level prevailing in the country. Similarly, partisan opposition voters have significantly more negative assessments than everyone else. Secondly, income growth is significantly associated with positive pocketbook assessments. Thirdly, government media is a strong predictor of all economic assessments. A related finding is that pro-government media viewers are more likely to assess the national economy favourably compared to their own pocketbook: When we subtract the respondent's pocketbook score from her sociotropic score, and run the regression to estimate the difference (which we call as "sociotropic overestimation," seen in column IV), pro-government media is a significant predictor.

Table 2: Estimating economic assessments, limited controls model

\begin{tabular}{|c|c|c|c|c|c|}
\hline Dependent variable & $\begin{array}{l}\text { Retrospective } \\
\text { pocketbook }\end{array}$ & $\begin{array}{l}\text { Retrospective } \\
\text { sociotropic }\end{array}$ & $\begin{array}{l}\text { Comparative } \\
\text { Prospective }\end{array}$ & $\begin{array}{c}\text { Sociotropic } \\
\text { overest. }\end{array}$ & $\begin{array}{c}\text { Price index } \\
\text { (logged) }\end{array}$ \\
\hline Estimation tech. & \multicolumn{4}{|c|}{ Ordered probit } & OLS \\
\hline \multirow{2}{*}{ Left-right } & $0.076 * * *$ & $0.069 * * *$ & $0.094 * * *$ & -0.001 & $-0.008 * *$ \\
\hline & $(0.012)$ & $(0.014)$ & $(0.016)$ & $(0.011)$ & $(0.004)$ \\
\hline \multirow[t]{2}{*}{ Income level } & $0.049 * *$ & 0.008 & 0.028 & $-0.046 * *$ & $-0.021 * * *$ \\
\hline & $(0.025)$ & $(0.027)$ & $(0.031)$ & $(0.020)$ & $(0.007)$ \\
\hline \multicolumn{6}{|c|}{ Partisanship, baseline: (1) Partisan pro-incumbents } \\
\hline \multirow[t]{2}{*}{ (2) Swing pro-incum. } & $-0.550 * * *$ & $-0.446^{* * *}$ & $-0.327 * *$ & 0.000 & -0.003 \\
\hline & $(0.095)$ & $(0.056)$ & $(0.157)$ & $(0.000)$ & $(0.018)$ \\
\hline \multirow[t]{2}{*}{ (3) Swing oppos. } & $-0.944 * * *$ & $-0.895 * * *$ & $-1.004 * * *$ & 0.067 & $0.063 * * *$ \\
\hline & $(0.093)$ & $(0.094)$ & $(0.169)$ & (0.108) & $(0.020)$ \\
\hline \multirow[t]{2}{*}{ (4) Partisan oppos. } & $-1.279 * * *$ & $-1.434 * * *$ & $-1.573 * * *$ & -0.082 & $0.148 * * *$ \\
\hline & $(0.109)$ & $(0.113)$ & $(0.195)$ & $(0.075)$ & $(0.026)$ \\
\hline \multirow{2}{*}{ 1-year income growth } & $0.009 * *$ & 0.005 & 0.005 & -0.005 & -0.000 \\
\hline & $(0.005)$ & $(0.004)$ & $(0.006)$ & $(0.004)$ & $(0.001)$ \\
\hline \multirow[t]{2}{*}{ Pro-govt media } & $0.258 * * *$ & $0.384 * * *$ & $0.419 * * *$ & $0.190 * *$ & $-0.037 *$ \\
\hline & $(0.069)$ & $(0.083)$ & $(0.104)$ & $(0.078)$ & $(0.021)$ \\
\hline $\mathrm{N}$ & 2,170 & 2,148 & 2,070 & 2,146 & 2,085 \\
\hline McFadden's Adj R ${ }^{2}$ & 0.12 & 0.13 & 0.20 & 0.11 & 0.09 \\
\hline
\end{tabular}

$* p<0.1 ; * * p<0.05 ; * * * p<0.01$, standard errors (in parentheses) clustered at province level and bootstrapped with 1000 replications. Intercept and cut-off points estimated but not shown

To interpret the effect magnitudes, the graph below illustrates the predicted probabilities of different pocketbook assessments for those who watch pro-govt TV and the rest, as income growth goes from the lowest to the highest values observed in the sample. Partisanship is held constant at "swing-pro-incumbent," the category closest to the sample mean. While 
pocketbook assessments are measured in 5 response categories, for presentation purposes we illustrate predicted probabilities for response values 1 "personal economic situation became much worse" and 4 "better". 7

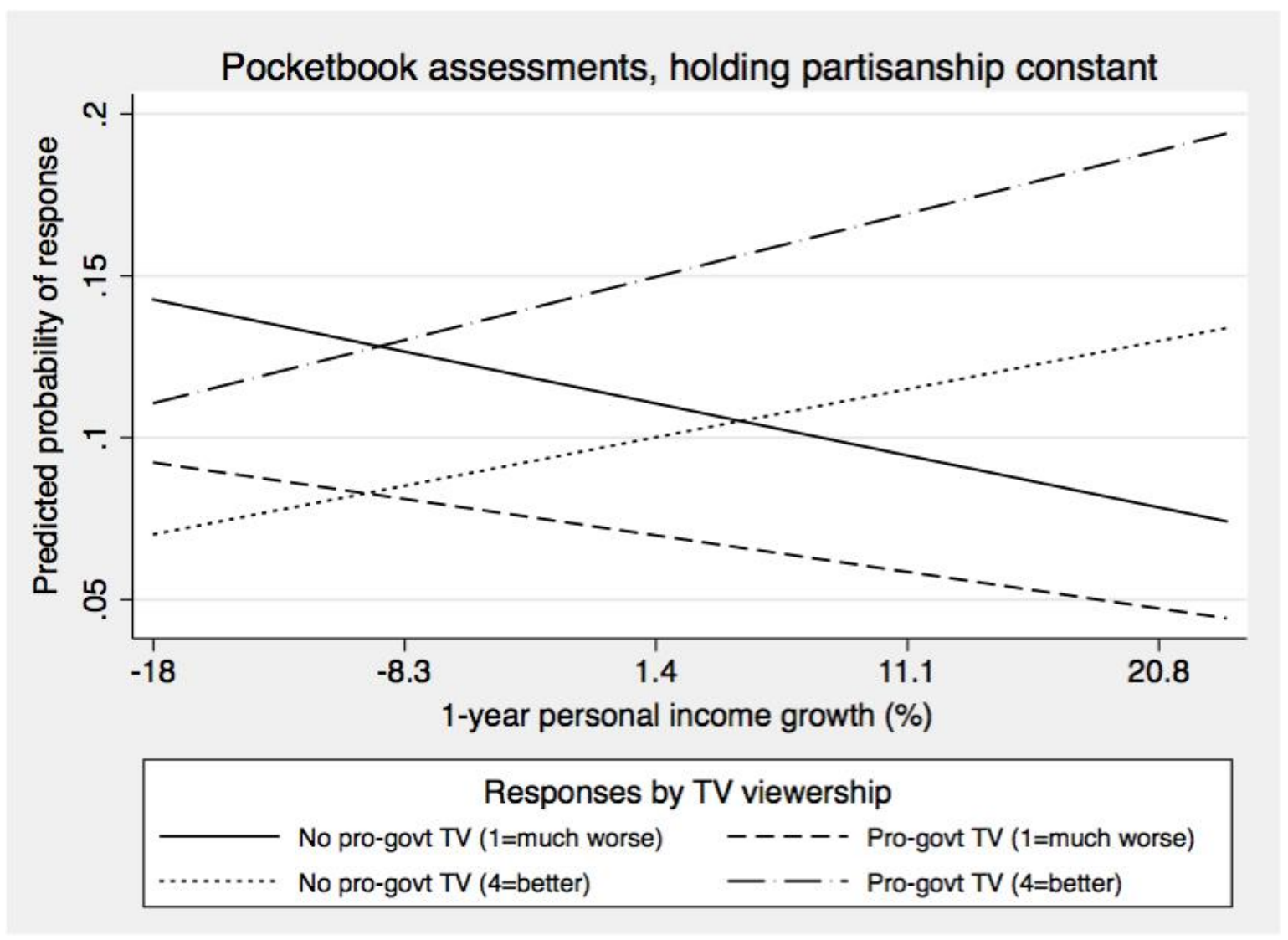

Figure 2: Effects of income growth and TV media, based on Table 2. Income growth is centered on the mean and shown in value intervals corresponding to 1 standard deviation

The graph shows that a swing pro-incumbent voter is about $65 \%$ to $74 \%$ more likely to think that her economic situation got better if she has experienced the highest income growth in the sample, compared to the lowest income growth. The likelihood would be $39 \%$ to $48 \%$ higher if she is watching the news on pro-government $\mathrm{TV}$, compared to if she is watching other channels or no TV. Since individuals are more likely to watch pro-government TV than being at the extreme ends of the income growth spectrum, the effect of media is critical. In other

\footnotetext{
${ }^{7}$ Since at the time of the survey Turkish economy was doing badly, the response category 5 "much better" was chosen by only 21 respondents in the entire survey and does not provide meaningful variation.
} 
words, holding past vote and positive/negative partisanship constant, media and actual income growth have substantial and roughly comparable effects. These findings lend support to the basic hypotheses $\mathrm{H} 1, \mathrm{H} 2, \mathrm{H} 3$.

We now refine the test for robustness with various model specifications. They include a no-controls model. An additional set of controls add variables that do not have a theoretically expected relationship with economic assessments but which are nonetheless known to affect individual attitudes at large: gender, age (in 3 groups), education level (below high school, high-school degree, university degree), and settlement type (rural, city, metropolis). Lastly, the full controls add country-specific identity cleavages that are known to help drive political behavior in Turkey: ethnicity (Kurdish or not), sect (Sunni or not), and level of religiosity (1-5). In addition, we also test models with pre-estimation matching and an instrumental variable for media, as will be explained later.

Table 3: Models used for testing robustness

\begin{tabular}{|c|c|c|c|c|c|}
\hline & $\begin{array}{l}\text { No } \\
\text { controls }\end{array}$ & $\begin{array}{l}\text { Limited } \\
\text { controls }\end{array}$ & Rich controls & Full controls & $\begin{array}{l}\text { Matching } \\
\text { model }\end{array}$ \\
\hline $\begin{array}{l}\text { Main variables: growth; } \\
\text { pro-govt media; } \\
\text { partisanship }\end{array}$ & Yes & Yes & Yes & $\begin{array}{l}\text { Yes (also } \\
\text { rerun with } \\
\text { instrument) }\end{array}$ & Yes \\
\hline $\begin{array}{l}\text { Limited controls: income } \\
\text { level; left-right position }\end{array}$ & None & Yes & Yes & Yes & Yes \\
\hline Additional controls & None & None & $\begin{array}{l}\text { age; gender; } \\
\text { education; } \\
\text { settlement }\end{array}$ & $\begin{array}{l}\text { age; gender; } \\
\text { education; } \\
\text { settlement; } \\
\text { Kurd; Sunni; } \\
\text { religiosity }\end{array}$ & religiosity \\
\hline $\begin{array}{l}\text { Pre-estimation matching } \\
\text { (media as treatment) on: } \\
\text { age; gender; education; } \\
\text { settlement; Kurd; Sunni }\end{array}$ & None & None & None & None & $\begin{array}{l}\text { Matching } \\
\text { applied }\end{array}$ \\
\hline Clust. (province) s.e. & Yes & Yes & Yes & Yes & Yes \\
\hline Bootstrapped s.e. & Yes & Yes & Yes & Yes & No \\
\hline $\mathrm{N}$ (for pocketbook) & 2170 & 1825 & 1825 & 1779 & 1654 \\
\hline
\end{tabular}

The initial findings are confirmed under different specifications. Moreover, with rich and full controls, the income growth variable grows stronger and also attains significance for 
sociotropic assessments. Media, on the other hand, retains its substantial effects on all dependent variables. The results are summarized in table 4, where the effects of income growth and media are reported as y-standardized coefficients. This enables us to test H4, which made a restrictive prediction: the influence of income growth should become smaller, and the influence of media should become larger as the dependent variable changes from pocketbook to sociotropic and to comparative prospective assessments. Since the assessments are in different scales (1-5 in retrospective assessments and 1-3 in the prospective one), to compare the effect of a given predictor variable across them, we can check how many standard deviations of difference in the dependent variable is associated with change in the predictor (Karlson, 2015). Across all models the key insight of the prediction holds: income growth is more and media is less strongly associated with varying attitudes when it comes to pocketbook assessments, compared to other assessments. The exact effect ranking is observed when some controls are present.

Table 4: Y-standardized coefficients (ordered probit coefficients as a ratio of standard deviation for each dependent variable), controlled for partisanship

\begin{tabular}{|l|l|l|l|l|}
\hline & & $\begin{array}{l}\text { Retro. } \\
\text { Pocket. }\end{array}$ & $\begin{array}{l}\text { Retro. } \\
\text { Socio. }\end{array}$ & $\begin{array}{l}\text { Comp. } \\
\text { prospective }\end{array}$ \\
\hline \multirow{2}{*}{ I) No controls } & 1 -year income growth & $0.007^{*}$ & 0.004 & 0.004 \\
\cline { 2 - 5 } & Pro-govt TV & $0.264^{* * *}$ & $0.342^{* * *}$ & $0.333^{* * *}$ \\
\hline \multirow{2}{*}{ II) Limited controls } & 1 -year income growth & $0.008^{* *}$ & 0.004 & 0.004 \\
\cline { 2 - 5 } & Pro-govt TV & $0.214^{* * *}$ & $0.31^{* * *}$ & $0.319^{* * *}$ \\
\hline \multirow{3}{*}{ III) Rich controls } & 1 -year income growth & $0.01^{* * *}$ & $0.006^{*}$ & 0.006 \\
\cline { 2 - 5 } & Pro-govt TV & $0.222^{* * *}$ & $0.316^{* * *}$ & $0.32^{* * *}$ \\
\hline \multirow{2}{*}{ IV) Full controls } & 1 -year income growth & $0.01^{* *}$ & $0.006^{* *}$ & 0.007 \\
\cline { 2 - 5 } & Pro-govt TV & $0.2^{* * *}$ & $0.285^{* * *}$ & $0.306^{* * *}$ \\
\hline \multirow{2}{*}{ V) Matching } & 1 -year income growth & $0.008^{* *}$ & $0.005^{*}$ & 0.005 \\
\cline { 2 - 5 } & Pro-govt TV & $0.186^{* * *}$ & $0.277^{* * *}$ & $0.254^{* * *}$ \\
\hline \multirow{2}{*}{$\begin{array}{l}\text { VI) Instrumental } \\
\text { variable }\end{array}$} & 1 -year income growth & $0.010^{* * *}$ & $0.006^{* *}$ & 0.008 \\
\hline \multirow{2}{*}{ Predicted by H4 } & Pro-govt TV instrument & 0.847 & $1.259^{*}$ & $1.700^{* *}$ \\
\cline { 2 - 5 } & 1 -year income growth & biggest & medium & smallest \\
\cline { 2 - 5 } & Pro-govt TV & smallest & medium & biggest \\
\hline
\end{tabular}

$* p<0.1 ; * * p<0.05 ; * * * p<0.01$, clustered standard errors (not shown) bootstrapped with 1000 replications 
For further robustness, we replicate the basic analysis by subjecting it to matching. Originally developed for controlled experiments, matching is also widely used as a preprocessing technique for regression analysis of data without a randomly assigned treatment. It involves dropping observations that have no close matches on pretreatment covariates (such as education or gender) in both the treated and the control groups - in our case, progovernment media viewers and the rest, respectively. To generate matches, we employ the coarsened exact matching (CEM) technique, which requires fewer assumptions about the data generation process and thus avoids certain problems in commonly used techniques such as propensity score matching (Iacus et al., 2011). CEM generates matching weights that can be utilized in regression analysis, which we do using the CEM package in Stata. We match the respondents on gender, age, education level, ethnicity, sect, and settlement type. Before matching, the sample is imbalanced on most of these variables, e.g. there are more people without high school degrees among the pro-government media audience compared to the rest of the sample. CEM reduces the imbalance substantially, bringing the Multivariate L1 distance from 0.41 to 0.27 (detailed in Appendix). Matching on other covariates would either drop more observations or increase imbalance. After matching the respondents on these categories, we estimate regressions controlling for demographics with a continuous nature: religiosity, left-right self-placement and income level, in addition to our chief variables of interest, completing the full controls list. The results of the matching analysis (summarized in Table 4) turn out to be very similar to the earlier findings reported.

For a last replication test we employ a 2-stages instrumental variable (IV) regression, where in the first stage we instrument the share of pro-government TV viewership in geographic location defined by settlement type (urban, rural, metropolis) per each province to predict media for individual respondents (varying across 56 values) with OLS, then in a second stage we rerun the rich controls ordered probit model $(\mathrm{N}=1779)$ to estimate individual 
economic assessments, this time utilizing this instrumented media variable. The share of progovernment TV viewership in each location may reflect local tastes and preferences of media consumption. Since respondent location is presumably prior to his media choice, location can serve as an exogeneous instrument for media effects on economic views, ruling out the reverse causation pathway. Although far from perfect, the IV model can therefore be used for a robustness check. ${ }^{8}$ The Kleibergen-Paap F statistics show that the instrument for media is strong 9 . The results (summarized in Table 4, present in Appendix B.2) are largely in line with previous findings in terms of the coefficient rankings, lending support to $\mathrm{H} 1, \mathrm{H} 2, \mathrm{H} 3$, and H4.

Moving on, H5 predicted that the association between income growth and pocketbook assessment, between pocketbook and sociotropic assessments, and between sociotropic and comparative prospective assessments should be weaker among the viewers of progovernment media. In Table 5 we go back to the simple limited controls model to test this prediction through a subgroup analysis where regressions are run separately for progovernment media viewers and everyone else. In line with our predictions, the effect of income growth on pocketbook assessment attains significance only for those who do not watch pro-government $\mathrm{TV}$, and the association between pocketbook and sociotropic assessment is significant for both groups but weaker for the pro-government TV audience. The same comparison applies to the association between sociotropic and comparative prospective assessments, too.

\footnotetext{
${ }^{8}$ It could be argued that location has effects on views other than through the media channel, but such effects should already be accounted for growth, partisanship and the control variables.

${ }^{9}$ Kleibergen-Paap F statistics for the estimations for pocketbook, sociotropic and comparative prospective assessments are respectively 20.529,19.380, 18.447, which are Stock Yogo weak ID critical test values (16.38) for a 0.1 maximal IV size (See Appendix).
} 
Table 5: Ordered probit analysis of economic assessments, across media viewership

\begin{tabular}{|c|c|c|c|c|c|c|}
\hline \multirow{2}{*}{$\begin{array}{l}\text { Dependent variable } \\
\text { Pro-govt. media }=\end{array}$} & \multicolumn{2}{|c|}{ Pocketbook } & \multicolumn{2}{|c|}{ Sociotropic } & \multicolumn{2}{|c|}{ Comparative Prospective } \\
\hline & 1 & 0 & 1 & 0 & 1 & 0 \\
\hline \multicolumn{7}{|l|}{ Independent variables: } \\
\hline Left-right & $\begin{array}{c}0.049 * * \\
(0.023)\end{array}$ & $\begin{array}{c}0.088 * * * \\
(0.016)\end{array}$ & $\begin{array}{l}-0.006 \\
(0.021)\end{array}$ & $\begin{array}{c}0.044 * * * \\
(0.017)\end{array}$ & $\begin{array}{c}0.081^{* *} \\
(0.039)\end{array}$ & $\begin{array}{c}0.081 * * * \\
(0.020)\end{array}$ \\
\hline Income level & $\begin{array}{c}0.138 * * * \\
(0.053)\end{array}$ & $\begin{array}{c}0.033 \\
(0.024)\end{array}$ & $\begin{array}{c}0.040 \\
(0.037)\end{array}$ & $\begin{array}{l}-0.055^{*} \\
(0.029)\end{array}$ & $\begin{array}{l}0.068 \\
(0.062)\end{array}$ & $\begin{array}{c}0.034 \\
(0.038)\end{array}$ \\
\hline \multicolumn{7}{|c|}{ Partisanship, baseline: (1) Partisan pro-incumbents } \\
\hline (2) Swing pro-incum. & $\begin{array}{c}-0.431 * * * \\
(0.105)\end{array}$ & $\begin{array}{c}-0.772 * * * \\
(0.187)\end{array}$ & $\begin{array}{l}-0.134 \\
(0.105)\end{array}$ & $\begin{array}{c}-0.123 \\
(0.141)\end{array}$ & $\begin{array}{c}0.000 \\
(0.000)\end{array}$ & $\begin{array}{c}0.000 \\
(0.000)\end{array}$ \\
\hline (3) Swing oppos. & $\begin{array}{c}-0.951 * * * \\
(0.104)\end{array}$ & $\begin{array}{c}-1.041 * * * \\
(0.129)\end{array}$ & $\begin{array}{c}-0.418 * * * \\
(0.160)\end{array}$ & $\begin{array}{c}-0.371 * * * \\
(0.116)\end{array}$ & $\begin{array}{l}-0.213 \\
(0.215)\end{array}$ & $\begin{array}{l}-0.206 \\
(0.203)\end{array}$ \\
\hline (4) Partisan oppos. & $\begin{array}{c}-0.938 * * * \\
(0.165)\end{array}$ & $\begin{array}{c}-1.390 * * * \\
(0.147)\end{array}$ & $\begin{array}{c}-1.222 * * * \\
(0.243)\end{array}$ & $\begin{array}{c}-0.791 * * * \\
(0.178)\end{array}$ & $\begin{array}{c}-0.937 * * * \\
(0.208)\end{array}$ & $\begin{array}{c}-0.768 * * * \\
(0.184)\end{array}$ \\
\hline 1-year income growth & $\begin{array}{c}0.007 \\
(0.006)\end{array}$ & $\begin{array}{l}0.011^{*} \\
(0.006)\end{array}$ & & & & \\
\hline Pocketbook & & & $\begin{array}{c}0.991 * * * \\
(0.089)\end{array}$ & $\begin{array}{c}1.191 * * * \\
(0.073)\end{array}$ & & \\
\hline Sociotropic & & & & & $\begin{array}{c}0.217 * * * \\
(0.054)\end{array}$ & $\begin{array}{c}0.321 * * * \\
(0.061)\end{array}$ \\
\hline $\mathrm{N}$ & 657 & 1,168 & 655 & 1,172 & 624 & 1,128 \\
\hline McFadden's Adj R ${ }^{2}$ & 0.05 & 0.9 & 0.20 & 0.29 & 0.12 & 0.16 \\
\hline
\end{tabular}

H5 receives support, then: While people rely on their pocketbook to judge the situation of the national economy, for those who watch pro-government TV this connection is significantly weaker. A related finding is that pro-government media viewers are more likely to assess the national economy favourably compared to their own pocketbook; as we previously (Table 2) showed with an analysis of "sociotropic overestimation." It is difficult to imagine why these particular patterns of variation, surviving the controls for partisanship and demographic covariates, could be a product of reverse causation running from economic assessments to media choice, so we take them as supportive evidence in favour of the argument of media effect. The findings testify both to the capacity of the individuals to anchor their assessments to personal experience, and to the media's ability to weaken the connections between an individual's personal experience and her assessment of the national performance. 
Before finishing, we would like to suggest that these effects of income growth and media have important implications on the voting behaviour. If we apply our full controls model (see Table 3) for a binary logistic estimation of the intention to vote for Erdogan in the next presidential election, a percentage point increase in the income growth variable will be associated with a 4 per cent increase in the odds ratio. This means that holding everything constant, as growth moves from 1 standard deviation below the mean to 1 above, the predicted probability to vote for the incumbent increases from 0.31 to 0.51 . This is comparable to the increase associated with watching government media, which increases the probability from 0.33 to 0.56 . The details of this vote estimate is in the Appendix B.4.

\section{Discussion and Conclusion}

In most settings we know of, favourable perceptions about economic performance increase the likelihood that a citizen will vote for the incumbent (Lewis-Beck and Stegmeier, 2000). In this article we analyzed how these perceptions are formed, utilizing income growth data from a pseudo-panel constructed with repeated comparable cross-sectional surveys in Turkey. Our results both confirm basic assumptions about the economic voting mechanism and generate new evidence regarding how economic assessments are formed. We find that differences in individual retrospective assessments can actually be predicted by income growth rates, and the association is stronger for pocketbook assessments. However, partisanship and media are important sources of bias, especially for sociotropic and prospective assessments. We present evidence for media's ability to weaken the connections between an individual's personal experience, her perception of the national performance, and her view of the imagined alternatives.

This also means that, when the economy is manifestly deteriorating, authoritarian incumbents may try to use their influence over mass media to convince the electorate that their own household experience does not reflect national reality and that the alternatives 
would be even worse. In a recent paper Guriev and Treisman (2018) write of leaders such as Putin and Erdogan as "informational autocrats", who aspire to be loved rather than feared, and bolster popular support for their regimes chiefly by the manipulation of information (also see Rozenas and Stukal, 2019). Previous studies have not tested in the individual level whether pro-government new is actually effective in bolstering favourable perceptions of economic performance. We now present evidence from Erdogan's Turkey compatible with this thesis. These findings should be highly relevant to hybrid regimes like Russia and Hungary, and arguably even to more liberal cases like USA where the President Trump has been directing supportive statements to what he sees as friendly media groups and verbal attacks towards non-friendly ones. 


\section{Works Cited}

Abramowitz, A. I., \& Webster, S. (2016). The rise of negative partisanship and the nationalization of US elections in the 21st century. Electoral Studies, 41, 12-22.

Alt, J. E., Marshall, J., \& Lassen, D. D. (2016). Credible Sources and Sophisticated Voters: When Does New Information Induce Economic Voting?. The Journal of Politics, 78(2), 327-342.

Anderson, C. J., Mendes, S. M., \& Tverdova, Y. V. (2004). Endogenous economic voting: evidence from the 1997 British election. Electoral Studies, 23(4), 683-708.

Ansolabehere, S., Meredith, M., \& Snowberg, E. (2011). Sociotropic voting and the media. In J. Aldrich, K. McGraw (Eds). Improving Public Opinion Surveys, 175-189. Princeton University Press.

Başlevent, C., \& Kirmanoğlu, H. (2016). Economic voting in Turkey: perceptions, expectations, and the party choice. Research and Policy on Turkey, 1(1), 88-101.

Becher, M., \& Donnelly, M. (2013). Economic performance, individual evaluations, and the vote: investigating the causal mechanism. The Journal of Politics, 75(4), 968-979.

Brug, van der, W., Eijk, C., Franklin, M., 2007. The Economy and the Vote: Economic Conditions and Elections in Fifteen Countries. Cambridge University Press, Cambridge.

Campbell, A., Converse, P. E., Miller, W. E. \& Stokes, D. E. (1960). The American Voter. Chicago, IL: University of Chicago Press.

Chiang, C. \& B. Knight. (2011). "Media bias and influence: Evidence from newspaper endorsements." The Review of Economic Studies 78(3):795-820.

Çarkoğlu, A., Baruh, L., \& Yıldırım, K. (2014). Press-party parallelism and polarization of news media during an election campaign: The case of the 2011 Turkish elections. International Journal of Press/Politics, 19(3), 295-317.

DellaVigna, S., \& Kaplan, E. (2007). The Fox News effect: Media bias and voting. The Quarterly Journal of Economics, 122(3), 1187-1234.

Domínguez, J. I., \& McCann, J. A. (1995). Shaping Mexico's electoral arena: The construction of partisan cleavages in the 1988 and 1991 national elections. American Political Science Review, 89(1), 34-48.

Duch, R. M., Palmer, H. D., \& Anderson, C. J. (2000). Heterogeneity in perceptions of national economic conditions. American Journal of Political Science, 44(4), 635-652.

Erikson, R. S., MacKuen, M. B., \& Stimson, J. A. (2002). The macro polity. Cambridge University Press.

Esen, B., \& Gumuscu, S. (2016). Rising competitive authoritarianism in Turkey. Third World Quarterly, 37(9), 1581-1606.

Evans, G., \& Andersen, R. (2006). The political conditioning of economic perceptions. Journal of Politics, 68(1), 194-207.

Ferree, M. M., Gamson, W. A., Rucht, D., \& Gerhards, J. (2002). Shaping abortion discourse. Cambridge University Press.

Ferrer-i-Carbonell, A., \& Frijters, P. (2004). How important is methodology for the estimates of the determinants of happiness? The Economic Journal, 114(497), 641-659.

Fiorina, M. P. (1981). Retrospective voting in American national elections. Yale University Press.

Fraile, M., \& Lewis-Beck, M. S. (2014). Economic vote instability: Endogeneity or restricted variance? Spanish panel evidence from 2008 and 2011. European Journal of Political Research, 53(1), 160-179.

Freedom House, 2014. Democracy in crisis: Corruption, media, and power in Turkey. Washington, DC: Freedom House. 
Funk, C. L., \& Garcia-Monet, P. A. (1997). The relationship between personal and national concerns in public perceptions about the economy. Political Research Quarterly, 50(2), 317-342.

Gerber, A. S., Karlan, D., \& Bergan, D. (2009). Does the media matter? A field experiment measuring the effect of newspapers on voting behavior and political opinions. American Economic Journal: Applied Economics, 1(2), 35-52.

Goidel, K., Procopio, S., Terrell, D., \& Wu, H. D. (2010). Sources of economic news and economic expectations. American Politics Research, 38(4), 759-777.

Green, D., Palmquist, B., \& Schickler, E. (2002). Partisan hearts and minds: Political parties and the social identity of voters. New Haven: Yale University Press.

Guriev, S. \& Treisman, D., 2018. Informational autocrats. Unpublished manuscript.

Hansford, T. G., \& Gomez, B. T. (2015). Reevaluating the sociotropic economic voting hypothesis. Electoral Studies, 39, 15-25.

Hansford, T. G., \& Gomez, B. T. (2015). Reevaluating the sociotropic economic voting hypothesis. Electoral Studies, 39, 15-25.

Healy, A., \& Malhotra, N. (2013). Retrospective voting reconsidered. Annual Review of Political Science, 16, 285-306.

Healy, A. J., Persson, M., \& Snowberg, E. (2017). Digging into the pocketbook: Evidence on economic voting from income registry data matched to a voter survey. American Political Science Review, 111(4), 771-785.

Hetherington, M. J. (1996). The media's role in forming voters' national economic evaluations in 1992. American Journal of Political Science, 372-395.

Iacus, S. M., King, G., \& Porro, G. (2012). Causal inference without balance checking: Coarsened exact matching. Political analysis, 20(1), 1-24.

Iyengar, S., \& Kinder, D. R. (1987). News that matters: Television and American opinion. University of Chicago Press.

Kalaycioğlu, E. (2018). Two elections and a political regime in crisis: Turkish politics at the crossroads. Southeast European and Black Sea Studies, 18(1), 21-51.

Karlson, K. B. (2015). Another look at the method of y-standardization in logit and probit models. The Journal of Mathematical Sociology, 39(1), 29-38.

Kayser, M. A., \& Peress, M. (2012). Benchmarking across borders: electoral accountability and the necessity of comparison. American Political Science Review, 106(3), 661-684

KONDA. (2016). KONDA Barometresi: Kitle İletişim Araçları ve Sosyal Medya Etkisi Nisan 2016. Survey Report.

Kramer, G. H. (1983). The ecological fallacy revisited: Aggregate-versus individual-level findings on economics and elections, and sociotropic voting. American political science review, 77(1), 92-111.

Levitsky, S., \& Way, L. A. (2010). Competitive authoritarianism: Hybrid regimes after the Cold War. Cambridge University Press.

Lewis-Beck, M. S., \& Costa Lobo, M. (2011). Anchoring the Portuguese voter: Panel dynamics in a newer electorate. Political Research Quarterly, 64(2), 293-308.

Lewis-Beck, M.S., Nadeau, R. \& Elias, A. (2008). Economics, party, and the vote: Causality issues and panel data. American Journal of Political Science, 52(1), 84-95.

Lewis-Beck, M. S., \& Stegmaier, M. (2000). Economic determinants of electoral outcomes. Annual Review of Political Science, 3(1), 183-219.

Magaloni, B. (2006). Voting for autocracy: Hegemonic party survival and its demise in Mexico. Cambridge: Cambridge University Press.

Marschall, M., Aydogan, A., \& Bulut, A. (2016). Does housing create votes? Explaining the electoral success of the AKP in Turkey. Electoral Studies, 42, 201-212. 
Martin, G. J., \& Yurukoglu, A. (2017). Bias in cable news: Persuasion and polarization. American Economic Review, 107(9), 2565-99.

McGregor, M. R., Caruana, N. J., \& Stephenson, L. B. (2015). Negative partisanship in a multi-party system. Journal of Elections, Public Opinion and Parties, 25(3), 300-316.

Mutz, D. C. (1992). Mass media and the depoliticization of personal experience. American Journal of Political Science, 483-508.

Nadeau, R., Lewis-Beck, M. S., \& Bélanger, É. (2012). Economics and elections revisited. Comparative Political Studies, 46(5), 551-573.

Nadeau, R., Niemi, R.G. \& Amato, T. (2000). Elite economic forecasts, economic news, mass economic expectations, and voting intentions in Great Britain. European Journal of Political Research, 38(1), 135-170.

Palmer, H.D. \& Duch, R.M. (2001). Do surveys provide representative or whimsical assessments of the economy? Political Analysis, 9(1), 58-77.

Rozenas, A., \& Stukal, D. (2019). How autocrats manipulate economic news: Evidence from Russia's state-controlled television. Journal of Politics 81(3): 982-996..

Sanders, D., \& Gavin, N. (2004). Television news, economic perceptions and political preferences in Britain, 1997-2001. Journal of Politics, 66(4), 1245-1266.

Sanders, D., Marsh, D., \& Ward, H. (1993). The electoral impact of press coverage of the British economy, 1979-87. British Journal of Political Science, 23(2), 175-210.

Stevenson, R. T., \& Duch, R. (2013). The meaning and use of subjective perceptions in studies of economic voting. Electoral Studies, 32(2), 305-320.

Treisman, D. (2011). Presidential popularity in a hybrid regime: Russia under Yeltsin and Putin. American Journal of Political Science, 55(3), 590-609.

Tilley, J., Neundorf, A., \& Hobolt, S. B. (2018). When the pound in people's pocket matters. The Journal of Politics, 80(2), 555-569.

Weatherford, M. S. (1983). Economic voting and the "symbolic politics" argument: a reinterpretation and synthesis. American Political Science Review, 77(1), 158-174.

Wlezien, C., Franklin, M., \& Twiggs, D. (1997). Economic perceptions and vote choice: Disentangling the endogeneity. Political Behavior, 19(1), 7-17. 